\title{
Competition and Reform in Higher Education
}

\author{
Michael S. Pak \\ Korea Advanced Institute of Science and Technology (KAIST), Daejeon, Republic of Korea
}

\begin{abstract}
This paper attempts to provide a critical theoretical perspective on the effects of competition on universities, using historical data pertaining to the American higher education system as the main empirical base. Through archival research and a synthesis of critical findings in recent secondary literature, it attempts a long-term historical analysis and theoretical modeling to produce a typological understanding of the effects of competition on universities. It argues that competition does not necessarily have the same effects on universities as on business corporations, and can in fact lead to surprising, even paradoxical results. Namely, the alleged virtues of competition such as encouraging innovative spirit and a large variety of services offered applies to the higher education industry only to a limited extent. This is because, the paper explains, when the main object of competition is prestige, as in the case of the higher education industry, institutions avoid risky experiments that could jeopardize their prestige and tend to imitate more successful institutions, which results in institutional convergence, rather than a divergence in services offered. The paper goes on to argue that while numerous countries around the world have in recent years focused on making universities “competitive”, this world-wide trend in higher education reforms—often pursued as a matter of higher priority for the development of the knowledge economy-is based on flawed assumptions. Building on the theoretical discussion, the paper finally attempts to analyze some of the specific problems which have become prominent in recent higher education reforms.
\end{abstract}

Keywords: higher education, reform paradigm, prestige competition, institutional convergence, risk avoidance, university ranking

\section{Introduction}

Jamil Salmi-the Tertiary Education Coordinator of the World Bank's Human Development Network—begins his 2009 report The Challenge of Establishing World-Class Universities with the account of a "traumatic" incident in Malaysia, which led to the resignation of the Vice-Chancellor of the University of Malaysia. According to the September 2005 edition of THES (Times Higher Education Supplement), the almost incredible apparently happened: the world ranking of Malaysia's top two universities had slipped by almost 100 places from the previous year. Along with many other countries around the world, Malaysia had been pursuing an ambitious plan to build the state-of-the-art knowledge economy infrastructure, with focused investments in the reform of its top-tier universities. What had gone wrong? There was nothing in particular that Malaysia did wrong, it turned out: THES had simply begun to use a different ranking methodology (Salmi, 2009, p. 1).

Salmi assures us that, though the Malaysian example is perhaps somewhat "extreme", the experience is

Michael S. Pak, Ph.D., Associate Professor, College of Cultural Science, Korea Advanced Institute of Science and Technology (KAIST).

Correspondence concerning this article should be addressed to Michael S. Pak, College of Cultural Science, KAIST, Daejeon, 305-701, Republic of Korea. E-mail: mpak@kaist.ac.kr. 
"not uncommon in university systems around the world". "Preoccupations about university rankings reflect", he observes, "the general recognition that economic growth and global competitiveness are increasingly driven by knowledge and that universities play a key role in that context” (Salmi, 2009, p. 1).

Though not discussed by Salmi explicitly in connection with this episode, what it also underscores is the fact that higher education reform is proving to be a difficult business. Since the 1990s higher education reform has been pursued as a matter of high priority by various countries around the world, but the results thus far appear to be mixed (Altbach \& Salmi, 2011). Some of the best intended and most ambitious reform plans have been known to misfire. Consider the recent experiences of Korea Advanced Institute of Science and Technology (KAIST), as another example.

As the country's top, government-run research university in science and technology, KAIST has recently been the focus of South Korea's ambitious plan to overhaul its tertiary education sector. Various experimental and controversial measures were introduced, in the hope not only that reforms would help boost KAIST's world rankings, but also that the institution's success would compel other universities in the country to follow its example. To make the plan work, top talents were recruited from abroad. In 2004, a Nobel-laureate physicist from Stanford was brought over to become its president (Zamiska, 2007). In 2006, he was succeeded by another American who, as a department chair at MIT, a member of the National Science Foundation, and a special advisor to President Ronald Reagan, had a proven track record as a successful reformer in the tertiary education sector. And all seemed to be going well—at first. Within the country, KAIST became the top ranked university of any category, besting even the Seoul National University, an older and bigger institution with a comprehensive set of academic programs besides those in science and engineering. KAIST's international ranking also steadily improved, and in some fields came to be within top 20 .

Yet beneath the surface, all was not well. The government's decision to force-feed reform was apparently resented by the faculty. The reason the Nobel laureate from Stanford served as president for only two years was essentially because of fierce faculty opposition (Zamiska, 2007). His successor, who in the interest of boosting the university's competitiveness introduced, among other reforms, a new set of tenure requirements, also provoked growing faculty opposition. And to make matters worse, the university began to experience a series of setbacks. With economic slowdown and changes in the country's political climate, government support for the university began to weaken. Funding for some of the universities' pilot research projects was reduced and then cut; whereas the university's new initiatives were once eagerly greeted with government support, it began to have difficulty getting funding increases even for new faculty hiring. Then in 2011 there were a series of suicides (involving four students and one faculty), which were blamed on stress due to unreasonable demands made by new reforms. Faculty opposition eventually came to be spearheaded by the newly formed University Senate, which began to demand the president's resignation (Chang \& Park, 2011). With the president refusing to concede, the university has been in stalemate ever since.

To be sure, it is too early to tell how it will all turn out. All may turn out well, in fact-not only for the countries thus far mentioned but also for others that have been similarly pursuing ambitious higher education reforms. Yet what also remains undeniable is that higher education reforms of recent decades have been, by and large, initiatives based guesswork: guesswork as to how to make universities more effective, guesswork as to what even constitutes an effective and successful university. Philip Altbach pithily summed the situation in his much-quoted description of "a world-class university” sought eagerly many countries: "everyone wants one, no one knows what it is, and no one knows how to get one" (Altbach, 2004). 
Yet, all of this has been symptomatic of a more fundamental problem in scholarship: namely, there have been no rigorously formulated reform paradigms for universities. Universities and their developmental patterns have not been examined with the same rigor as business firms. Among other things, they have not been subjected to theoretical modeling based on searching historical analysis to the same extent that business firms have been. To be sure, the scholarly literature on universities is immense. Yet this literature has been notorious for being long on information, and short on rigorous interpretation and analysis. And the subject under consideration being universities, a conflict of interests has also often been at work. As the historian Boorstin once wrote, "When a university professor writes about a university he adds his vested interests and provincial loyalties to all his other temptations" (Boorstin, 1967, p. 369).

As part of an effort toward formulating more rigorously studied reform paradigms in higher education, this paper focuses on a theme that has dominated the recent reform debates: competition. Since the fall of the Soviet Union and the rise of neoliberalism, market reform and competition have been embraced by numerous countries as the catchphrase solution for increasing efficiency in all sectors of society, and higher education reform has been no exception to this trend. The alleged virtues of promoting competition among universities have come to be accepted to such a degree that "effectiveness" and "competitiveness" have become near synonyms in reform debates on higher education.

In this paper, the author proposes that we need to consider uncoupling these two terms. We need to go back and ask whether what we assume about competition is true, whether competition is indeed likely to have the same effects on universities as, say, on business firms. To be sure, it is not easy, or even possible, to set up controlled experiments to test the effects of competition on universities. But it is still possible to learn a great deal from analyzing relevant historical data. What follows, then, is a historian's answer to current reform debates in higher education - $\mathrm{a}$ historian who has spent a long time studying the historical records relating to the developmental patterns of universities.

\section{Research Design and Method}

In this paper the author has followed research methods which are standard among historians: that is, formulating broad generalizations based on findings from manuscript sources and secondary literature. The arguments of this paper incorporate results from the author's own research on the history of the American tertiary education system and the findings regarding the American and other systems by various authorities. The reason for taking a focused look at the American system does not require much elaboration. It is not only that the United States has the largest number of highest-ranking research universities (According to the widely followed Academic Ranking of World Universities, all but three of the top 20 research universities in the world are American (ARWU, 2012)). The American system is also famously based on free competition and, as such, has been iconic among reform advocates in many parts of the world (Pak, 2010). In fact, the competitive higher education system of the United States has been in existence for more than two centuries, and can provide us with enough historical data to attempt a long-term analysis of the effects of competition on universities. Admirable and useful as are studies like Salmi's 2009 report and the case studies of 11 universities in different parts of the world he co-edited with Altbach in 2011, they only document the developments of the recent years, and are hence inadequate as a basis for theoretical modeling. As Salmi himself notes, world class universities may require centuries, not decades, to create (Altbach \& Salmi, 2011, p. 325). 


\section{Results}

As is standard in a historical discourse, the results are summed up only briefly in advance. A more elaborate presentation of the paper's arguments and their substantiation is provided in the discussion section below. In the first section of the discussion, the author argues that competition indeed may not have the same effects on universities as on business firms, and go on to elaborate on two "paradoxical" effects in particular. In the ensuing section, the author applies the insights developed in the first section to analyze why, under what conditions, competitive higher education systems like the American have proven successful, and what implications this might have for reform efforts elsewhere.

\section{Discussion}

\section{Paradoxes of Prestige Competition}

As Veblen pointed out long ago, what universities ultimately compete for is prestige (Veblen, 1918). His observations were primarily based on American universities almost a century ago. Veblen already noted that while universities compete for faculty, students, funding and so on in their day-to-day operations, all of this is meant to contribute to one final objective, which is to preserve or improve their standing. It is in terms of prestige, in other words, that the final score-keeping is done in higher education. The tendencies Veblen observed have become only more pronounced with time. In the United States, the success of a university is now measured, more than ever, in terms of how it ranks in influential evaluation reports like those published by the U.S. News and World Report. And the tendency has long since become international, as more and more countries have begun to use ranking systems like the THES and $A R W U$ to track the progress of their universities (Altbach \& Salmi, 2011, pp. 323-326).

Here lies the key to understanding the competitive behavior of universities. The paradoxical effects of competition among universities stem precisely from the fact that it is ultimately about prestige. For the developmental patterns resulting from prestige competition are often contrary to what one would normally expect.

The paradox of institutional convergence. One of the founding premises regarding competition-as to why it is beneficial to the customers - is that it leads to a greater variety of services offered by producers. Yet, this has not been true in higher education. In countries where universities have been allowed to compete freely, the predominant pattern has been a tendency toward institutional convergence, not institutional diversity or service differentiation. In such systems, it has been generally the case that the more universities compete, the more they imitate one another and become indistinguishable in the range of services they offer.

This tendency, which has been particularly pronounced in the American system, becomes all the more apparent when seen in contrast to what goes on in centralized, government-controlled systems like the French, where the state has been active in maintaining a high degree of institutional differentiation. In France, universities famously continue to focus on teaching, while the bulk of research is carried out at national research institutes. As is well known, the French model used to be influential in many parts of the world, especially in the Soviet Union and the Eastern bloc countries (Pak, 2000, pp. 19-23).

To be sure, the American system has not been without its own version of institutional diversity. Besides research universities, liberal arts colleges, two-year community colleges and so on continue to operate in the United States. Yet in comparison to systems like the French, what is striking about the American system is that 
these do not constitute permanent or even mutually exclusive categories. In fact, institutions that are not comprehensive research universities tend to function as fragments thereof, duplicating and often competing in one or more areas of the latter's operations (In the famous California Master Plan for Higher Education of 1960 devised by Kerr, and which has been widely imitated since, students can thus freely transfer from one category of institution to another, as though two-year community colleges operate as a fragment of four-year state universities, and four-year state universities as a fragment of research universities that have a full array of graduate programs) (Kerr, 1994, pp. 111-125).

Nor has "category jumping” been unusual. Many institutions that have started out with a specialized focus have been known to "fill out" over time and become comprehensive research universities in their quest for greater prestige. MIT, for instance, started out as a technical school emphasizing vocational training. Over time, it expanded into a full-fledged research university, with world-class programs even in the humanities and social sciences. Likewise, Stanford was in its origin an institution created to serve the educational needs of the working poor, but like MIT, it has grown to become one of the world's premier research universities (Pak, 2000, pp. 23-24).

That institutional convergence of this type is a function of prestige competition is further corroborated by recent developments elsewhere. In a highly perceptive article published in OECD's Higher Education Management and Policy, Codling and Meek have observed that increasing institutional convergence has been almost invariably the norm in countries that have pursued deregulation in higher education and where government has made little effort to keep institutions operating in different orbits as in France. They have singled out two factors as primarily responsible for this tendency: first, "a desire for status emulation", and second, "a competitive spirit amongst universities". "In such a deregulated environment, with a uniform funding regime", they concluded, "institutions will inevitably tend to respond to similar stimuli in similar ways, and to become more and more alike” (Codling \& Meek, 2006, pp. 10-11).

The paradox of institutional convergence resulting from prestige competition is a two-edged sword, with positive as well as negative consequences. The positives are obvious. Over time, more and more institutions will do everything they can to become comprehensive research universities, in a bottom-up approach to expanding the research base of the country, as it were. The number of institutions that have upgraded themselves to become research universities in the United States has in fact grown from 14 in the beginning of the 20th century to over 200 in the early 21st century. And there are numerous other institutions which are only steps away from a full upgrade (Carnegie Foundation, 2012).

Yet there is also a down side to this tendency. What it implies is that while universities eagerly mimic more successful competitors, they do not deviate from the existing paradigm of success. That is to say, they try to become more and more like their successful rivals, instead of pursuing the strategy of trying something radically different. While prestige competition can help spread a new innovation quickly among universities, it in fact also inhibits universities from initiating new innovations before their competitors, especially innovations that are perceived as risky or truly out of the ordinary. Such risk avoidance is another major paradox resulting from prestige competition.

The paradox of risk avoidance. This is a paradox which truly flies in the face of conventional wisdom regarding competition. For one of the prime virtues of competition is supposed to be encouraging institutions to take risks. Prestige competition, however, has been known to make universities risk-averse. As former Harvard president Bok once observed: "faculties will resist new initiatives that are so large or so visible that failure 
could diminish the prestige of the institution or impair its ability to attract able students and talented professors. This inhibition seriously affects the likelihood of major reforms” (Bok, 1986, pp. 185-186). A 2001 RAND Corporation report on prestige competition in American higher education likewise notes that "prestige-based and prestige-seeking behavior tends to limit innovations" except for "marginal" changes, since American colleges and universities tend to "build prestige by essentially mimicking the institutions that already have prestige” (Brewer, Gates, \& Goldman, 2002, p. 66).

Counterintuitive as this tendency might seem, it begins to make more sense when one looks at the risk/reward profile for institutions in different stages of development.

(1) Top-ranking institutions: Purely from the standpoint of prestige competition, top-tier institutions have little to gain if a radical reform proves successful—since they are already at the top—but much to fear if it turns out to be a disaster. And even if they succeed, it will be a zero-sum game for them in any case, since their rivals will soon try to catch up and close the differentiation gap. The most rational course of action for them-one with the best risk/reward ratio-is therefore to wait and see, and play the catch-up game as it becomes necessary.

(2) Middling institutions: The question for them is whether to play a catch-up game to top-ranking institutions or try doing something radically different. Doing something radically different-something no one has tried before-is a highly risky move for them, since even if they succeed, there is no guarantee that their success will gain enough recognition. The least risky strategy is to persevere in the present course and follow the lead of the top institutions (Brewer, Gates, \& Goldman, 2002).

(3) Start-up institutions: The business world is where one would most expect to see innovations and risk-taking behavior. But here is where the differences between higher education and other industries become most obvious. In general, higher education has been an industry where start-up institutions have seldom been known to be able to muster the kind of funding and prestige necessary to compete with the best. As economists might say, it is an industry usually not open to a genuine threat of new competition. Numerous commentators on the long-term development of the American system have been intrigued by the fact that, despite free competition, the top 20 universities in the country have been more or less the same for almost a century (Graham \& Diamond, 1997; Thelin, 2004, pp. 354-357).

Historically, major reforms in American higher education have required stimulus from the outside the higher education sector, in the form of funding from philanthropic foundations or the government (Pak, 2010). This also makes sense. As long as the tuition fees and so on remain the main source of revenue, there is only so much new institutions can do to speed up the accumulation of surplus endowment such as, say, Harvard has taken centuries to build up. Hence the availability of outside funding-whether from philanthropic or government sources—-has been a necessary game changer.

To sum up, even in a competitive higher education system like the American, universities have been known to keep spinning their wheels when left to their own devices, making one minor change after another-and continuing to play "musical chairs" with the rankings of one program or another-instead of making a genuine movement forward. This is because the top-tier institutions would not lead, and the lower-tier institutions usually follow the lead of top-tier institutions.

\section{The "Golden Formula" and Difficulties in Its Application}

In The World is Flat, Friedman quotes Bill Gates, who rhapsodizes over the success of American research 
universities. "Our university system is the best", the founder of Microsoft notes, because the universities are "competitive" and the system keeps being oiled "with federal tax money, with some philanthropy on top of that" (Friedman, 2007, p. 331). As Geiger and Sá have noted, "Friedman pungently expressed a view that has now become conventional wisdom in many quarters” (Geiger \& Sá, 2008, p. 22).

It is indeed now all but conventional wisdom that the ingredients mentioned by Gates have been among the most important contributing factors for the proverbial success of American research universities. What has not received proper emphasis until now, however, is the fact that all of the ingredients may have been equally necessary, that the competition among universities alone is unlikely to have been enough to make universities effective innovators, for the reasons discussed in the previous section.

In fact, according to some, "the golden formula" Americans discovered in the 20th century for making universities highly entrepreneurial can be succinctly summarized as follows: institutional competition + government (and/or philanthropic) funding = effective and entrepreneurial universities (Pak, 2010).

The external funding (especially from the government) has been an essential component of the formula — and there also lies the main source of difficulty in duplicating it elsewhere. It has been one of the defining characteristics of the university-government relationship in the United States that, while the federal government has been a major provider of research funding, it has not tried to control universities or meddle in their management. The historian Dupree's formulation "the flow of funds with minimal interference" has been a characteristic description of the federal government's relationship with universities until recently (Dupree, 1986, p. xv).

Such an arrangement-alternatively described by some as being tantamount to "leaving money on the stump with no questions asked” (Altbach, Berdahl, \& Gumport, 2005, pp. 71-90) —is not an easy one to duplicate in today's environment, especially for countries that have recently joined the race for creating "world-class universities".

Governance issues. It is well-known that the recent higher education reforms pursued in many countries have been initiated and orchestrated by the government. While making universities competitive has been a universally pursued goal, there also appears to have been simultaneous recognition that the government initiative is helpful if not necessary in carrying out reforms, rather than leaving universities to their own devices (Salmi, 2009, pp. 36-50).

Yet in many countries the government participation in higher education reform also has not been of the type that could be characterized as "the flow of funds with minimal interference". Various procedures and processes have been generally introduced to ensure that universities are being accountable and making timely progress (Altbach \& Salmi, 2011, pp. 323-342). One potential source of friction in this arrangement has always been that there are likely to be two competing timelines at work. Governments often work with short time spans, since in many cases they need to able to show positive results more or less immediately, or at least before the next election. But creating a world class university is likely to require a considerably longer time horizon.

It turns out that "the flow of funds with minimal interference" took a lot of work to achieve even in the United States. There is a long history of lobbying efforts by universities in the United States to maintain their autonomy even while receiving government funding, and that history goes at least as far back as the late 19th century. Likewise going back to the late 19th century when the effort on the part of the American faculty to defend and fight to preserve academic freedom, not only against government interference but also against the undue interference of corporate sponsors and philanthropic foundations (Pak, 2000). 
The problems institutions like KAIST in South Korea have recently faced ultimately stem from governance issues. As a government-run institution, KAIST's presidents are selected by the board of trustees and ultimately require government approval. Even if they are selected from the existing faculty, presidents are in a delicate position, since they are liable to be treated by the faculty not as one of them, but as government representatives. And all the more so for presidents recruited from abroad to implement radical reforms. Even if they tried hard, it would have been difficult to prevent the perception of their being there as instruments of undue government interference, which was surely to be resented by the faculty. And at least the latter president has admitted that communication with the faculty has been one of main problems (Chang \& Park, 2011).

Ranking systems and accountability issues. If universities are given large amounts of funding, and not monitored closely by government officials, how can one make sure that they will make good use of public funds? How can one make sure that universities remain accountable? A truly constructive method for measuring the performance of universities is still an ongoing project (Altbach, Berdahl, \& Gumport, 2005, pp. 71-90). Even in the United States, crude quantitative metrics are used in some contexts-like the amount of federal grants earned per every dollar invested by the state government—but their limitations are widely acknowledged. Even the best known and most widely used ranking systems like THES and ARWU hardly seem fully adequate (Jamil, 2009, pp. 1-10). How can anyone take seriously a ranking system that changes the ranking of the same universities by almost 100 places within a year? It is likely the ranking system that is at fault, not the universities.

Moreover, it would be an understatement to say that the most major ranking systems in use today put systems like the French at an unfair disadvantage (Altbach \& Jamil, 2011, p. 324). France does not have high-ranking research universities. But does that mean France is not a leading nation in research? Absolutely not. But the current university ranking systems are liable to give that false impression, simply because under the French system research is done at institutes, not universities. Academics are usually intelligent enough to know that comparing apples and oranges using the same metrics is often a bad practice, and yet that is precisely what is being done under the current ranking systems.

\section{Conclusions}

From above discussions, it is difficult to escape the conclusion that there is an urgent need for new reform paradigms in higher education. The paradigms which have been thus far used are based on a faulty or incomplete understanding of the systems that are supposedly being used as models, as well as success metrics that have been admittedly inadequate. The result has been an almost surreal game where Altbach's description of "a world-class university" has proven so apt: "everyone wants one, no one knows what it is, and no one knows how to get one" (Altbach, 2004).

What has prevailed thus far, and is still in the process of expanding across the globe, is a competitive game based on elusive and sometimes misleading statistics, which may or may not lead to the professed end goals of helping equip countries with the infrastructure necessary for the knowledge economy of the 21st century.

The future is difficult to predict, and it is equally difficult for those who debate and speculate on higher education policy to set up controlled experiments to test their hypotheses. But one can still learn a great deal from history. Accurate historical analysis can go a long way, and so can flexible thinking based on knowledge and common sense. 


\section{References}

Academic Ranking of World Universities (ARWU). (2012). ARWU rankings in 2012. Retrieved from http://www.arwu.org

Altbach, P. (2004). Costs and benefits of world-class universities. Retrieved from http://www.aaup.org/AAUP/pubres/academe/2004/JF/Feat/altb.htm

Altbach, P., \& Salmi, J. (2011). The road to academic excellence: The making of world-class research universities. Washington, D.C.: World Bank.

Altbach, P., Berdahl, R. O., \& Gumport, P. J. (2005). American higher education in the twenty-first century: Social, political, and economic challenges (2nd ed.). Baltimore and London: Johns Hopkins.

Bok, D. (1986). Higher learning. Cambridge, M.A.: Harvard.

Boorstin, D. J. (1967). Universities in the republic of letters. Perspectives in American History, 1, 369-379.

Brewer, D. J., Gates, S. M., \& Goldman, C. A. (2002). In pursuit of prestige: Strategy and competition in U.S. higher education. New Brunswick: Transaction.

Carnegie Foundation. (2012). Basic classification tables. Retrieved from http:// www.carnegiefoundation.org

Chang, D., \& Park, C. (2011). Professor's presidency criticized. The Technology (p. 1). Cambridge, M.A.: MIT.

Codling, A., \& Meek, V. L. (2006). Twelve propositions on diversity in higher education. Higher Education Management and Policy, 18(3), 1-16.

Dupree, A. H. (1986). Science in the federal government: A history of policies and activities. Baltimore and London: Johns Hopkins.

Friedman, T. L. (2007). The world is flat: A brief history of the twenty-first century (3rd ed.). New York: Picador.

Geiger, R. L., \& Sá, C. M. (2008). Tapping the riches of science: Universities and the promise of economic growth. Cambridge, M.A.: Harvard.

Graham, H. D., \& Diamond, N. (1997). The rise of American research universities: Elites and challengers in the postwar era. Baltimore: Johns Hopkins.

Kerr, C. (1994). Higher education cannot escape history: Issues for the twenty-first century. Albany: SUNY.

Pak, M. (2000). Academia Americana: The transformation of a prestige system (Doctoral dissertation, Harvard University).

Pak, M. (2010). The entrepreneurial university: The American model and its relevance for the global science and technology parks movement. Proceedings from STP '10: The 27th IASP World Conference on Science and Technology Park. Malaga: International Association of Science Parks.

Salmi, J. (2009). The challenge of establishing world-class universities. Washington, D.C.: World Bank.

Thelin, J. R. (2004). A history of American higher education. Baltimore and London: Johns Hopkins.

Veblen, T. (1918). Higher learning in America: A memorandum on the conduct of universities by business men. New York: B. W. Huebsch.

Zamiska, N. (2007). As it struggles to change, school mirrors Korea’s woes. The Wall Street Journal (p. A1). 